JURIS ĒRENPREISS, ANDREIS IVANOVS

\title{
ZOBĀRSTNIECĪBAS ATTĪSTĪBA LATVIJĀ
}

\section{Latvijas zobārstniecības attīstības priekšnoteikumi}

Zobārstniecība Latvijā sāka attīstīties samērā vēlu. Ilgu laiku tai tika piešḳirta otrškşirīga loma, tầpat kā citur pasaulē. Protēzes gan bija pazīstamas jau pirms trim tūkstošiem gadu, taču tās izgatavoja nevis ārsti, bet gan juvelieri. Savukārt urbji zobu labošanai tika izgudroti pirms 160 gadiem [1].

Par zobārstniecību kā atsevišḳu medicīnas nozari sāka runāt 17. gs. b. - 18. gs. sāk. Nedaudz vēlāk parādījās jēdziens "stomatologija". 20. gs. sākumā zobārstniecỉbu iedalīja trīs lielās nozarēs: konservatīvā zobārstniecība, zobu ḳirurğija, žoklu ortopēdija.

Par zobu stāvokli Latvijas teritorijas iedzīvotājiem senos laikos esošãs liecĩbas rāda, ka zobu slimības bija loti izplatītas. R. Denisova pēc t.s. Zvejnieku kapsētas materiāliem (cilvēka galvaskausi no mezolīta beigām un neolìta sākuma) konstatêjja, ka kariesa indekss (vidējais kariozo zobu skaits vienam cilvēkam) bija 16,67. Tika atklāts arī osteomielīts kā slimu zobu komplikācija [2]. Feodālisma laikā Latvijas teritorijā kariesa sastopamība (pēc izrakumu datiem) bija 39,1\% tâ̄tad zobu stāvoklis bija vēl pasliktinājies [4]. Vēlīnā feodālismā zobu kariesa sastopamība sasniedza apmēram $45 \%$. Mūsu laikos zobu stāvoklis ir daudz sliktāks un sasniedz $70-90 \%[5,6]$.

Viduslaikos tagadējās Latvijas teritorijā zobārstniecỉba bija saistīta galvenokārt ar ķirurgiju, zobārsti kā tādi netiek minēti. Ar zobu raušanu nodarbojās arī klejojošie ārsti [3]. 19. gs. Latvijā parādās zobārsti, kas bija mācỉjušies ârzemju universitātēe, kā arī praktiḳi bez izglîtības, kuri bija nokārtojuši eksāmenus Krievijas augstskolās.

Par zobārstniecības stāvokli 19. gs. vidū liecina 88 gadus vecā Antona Fausteina fiksētā liecība 1940. gadā: "Toreiz Rīgā bija trīs zobārsti. Divi-pašā pilsētas centrā -Vallensteins un Bollingers, un Pētera priekšpilsētāa, Baznīcas ielā-Dulkeits, kas bija mäcījies pirtnieka amatam un vēlāk praktizēja kã zobārsts. Vidusškirirā bija pienemts likt raut zobu, tikko tas sāka sāpēt. Zobu izmeklēšanu izdarīja, apskatot zobus un piebungojot tiem, lai atrastu sãpigo, sevišķi tad, ja bija vairāki bojāti 
zobi. Tad ar mazu nazi atbrīvoja zobu no smaganām un izrāva to ar stangu vai speciālas zobatslēgas palīdzību. Māceklim vajadzēja turēt pacienta galvu; pie darba stājās ātri, jo citādi pacients zaudēja drosmi vai arī no uztraukuma viñam pärgāja zobu sāpes. Ja zobu sāpes cēlās no smaganu iekaisuma, bet paši zobi bija veseli, tad pielika dēles: I-2 gab. pie smaganām. lekaisumam izbeidzoties, pärgãja arī sāpes. Grütniecēm deva apmierinošus lïdzeklus. Viñām zobus nerāva." [7]

ledzīvotāju sliktais zobu stãvoklis, zobu sāpes un biežãs mutes dobuma slimību komplikācijas sekmēja attiecīgu rakstu parādīšanos jau pirmajos izdevumos latviešu valodā (lai gan arī ilgi pirms tam latviešu tautasdziesmās un parunās zobu slimïbas un to ārstēšana ar tautas līdzekliem tika atspogu|jota diezgan bieži; tas stipri ietekmêja zobu slimību ārstēšanu un mutes dobuma higiēnas ievērošanu).

Pamatojoties uz 1838. gadā Krievijā pieñemto likumu, ar zobārstniecību tika at|jauts nodarboties tikai t.s. dentistiem. Par tâdu varēja k|ūt jebkurš cilvēks bez izglītības, kurš varēja pierādīt, ka vismaz trīs gadus ir mãcījies pie kāda ievērojama dentista. 19. gs. statistika rāda, ka 1856. gadā Vidzemē bijuši 6 dentisti, Kurzemẽ - neviens, 1886. gadā Vidzemē to bija jau 20, bet Kurzemē - 6; 1902. gadā to jau ir attiecīgi - 80 un 22 [1].

Sistemātiska zobārstu sagatavošana Krievijā sākās 1881. gadā, kad Pēterburgā atklāja pirmo zobārstniecỉbas skolu. Pēc desmit gadiem tika pieņemts likums, ka šajā skolā var iestāties tikai cilvēki, kas ieguvuši sešu klašu izglîtỉbu ġimnāzijā. Tas sekmēja zobārstu kvalifikācijas celక̌anos.

Zobārstniecỉbas skolas tika atklātas tikai tajās pilsētās, kurās bija universitātes, jo pêc skolas beigšanas topošajam zobārstam bija jākārto eksămeni universitātes medicīnas fakultātē. Izñēmuma kārtā šādu skolu at|āva atvērt Rīgã ar noteikumu, ka tâs beidzēji kārtos eksāmenus Tērbatas universitātẽ.

Neraugoties gan uz zobārstu skaita un kvalifikācijas, gan uz sabiedrības sanitārhigiēniskā līmena celšanos, 20. gs. sākumā joprojām bija izplatītas senās zobārstniecíbas metodes. Piemēram, 1910. gadā Jaunā Dienas Lapa rakstīja, ka uz sãpoక̌iem zobiem ir jāuzliek pipari, sāls, tabaka, odekolons, ožamais spirts, ūdens, konjaks, ledus, karbolskābe, etiķis utt. Tỉka saglabẫta arī vēl viena viduslaiku tradīcija: neraugoties uz to, ka frizieri savas ķirurgu tiesības bija zaudējuši, tie joprojām (kaut arī nelegāli) turpināja nodarboties ar zobārstniecỉbu. Piemēram, 1898. gadā avīze Baltijas Vēstnesis rakstīja: "..daži neaptēsti frizieri un matu griezēji joprojām rauj zobus, pie tam nem par to veselas piecdesmit kapeikas, kad izglītoti ârsti nem par šădu pakalpojumu rubli."

20. gs. 20. gadu sākumā Latvijā strādāja jau gandrīz 400 zobārstu (t.sk. trīs ceturtda|as Rīgā), bet 1928. gadā to bija jau 720 .

\section{Pirmā zobārstniecības skola Latvijā}

Kā jau minēts, 1891. gadā Krievijā tika izdots likums par zobārstniecības skolām, 
kurā bija teikts, ka zobārstniecības skolā var iestāties tikai cilvēki ar sešu klašu g̀imnāzijas izglītību. Mācības ilga piecus semestrus.

Pirmo zobārstniecības skolu Rīgã 1901. gadā atklāja Leo Dolins (agrāk - Judolovičs; dzimis 1864. gadā Kurzemē, 1892. gadā beidzis Tērbatas universitātes medicīnas fakultāti). Šĩ skola pastāvēja no 1901. līdz 1914. gadam. No 1904. līdz 1909. gadam skolai bija šảds absolventu skaits :

$$
\begin{aligned}
& \text { 1904. gadā }-33 \text {, } \\
& \text { 1905. gadā }-28, \\
& \text { 1906. gadā }-34, \\
& \text { 1907. gadā }-13, \\
& \text { 1908. gadā - 19, } \\
& \text { 1909. gadā - } 18 \text {. }
\end{aligned}
$$

Līdz 1907. gadam skolā strādāja 2 pasniedzēji, bet 1909 - 9; no 1902. gada līdz pat skolas slēgšanai tajā strādāja arī nākamais profesors Kẩrlis Barons [8].

\section{Zobārstniecības biedrības}

Latvijā zobārstu biedrības sāka veidoties 20. gs. sākumā. Vispārīgās ārstu biedrības, piemẽram, Rīgas Praktizējošo ārstu biedrỉba, pastāvēja jau 19. gs. Šāu biedrību veidošanos Baltijā kavēja sociālie un politiskie apstāk|i: gan Krievijas valdība, gan vietēja vācu muižniecība nebija ieinteresētas ārstu profesionālo biedrību izveidē. Mēg̀inājums dibināt latviešu ārstu biedrību tika atzīts par nevajadzīgu (Rīgas Praktizējošo ārstu biedrībā bija galvenokārt vācu tautības ārsti) [9]. Latviešu Ārstu biedrība dibināta 1902. gadā. Pirmie zobārstu biedrību aizmetñi attiecināmi uz 1905. gadu. Tika nodibinātas 2 biedrības: Rīgas Zobārstu biedrība (oficiāli gan reg̀istrēta Rīgas apgabaltiesā tikai 1922. gadā), kuras galvenie mērķi bija politisko un profesionālo jautājumu risināšana, bet izglītības un zinātnes problēmas bija otrajā plānā, un Rigaer Odontologischer Verein - šaurs, nacionāls vã̄cu zobārstu pulciņš, kura mērksis bija ārstu izglītỉbas un prakses pilnveidošana. Vēlāk dibināta Rīgas Odontologu biedrība (reg̉istrēta 1920. gadā).

1908. gadu var uzskatīt par Latviešu Zobārstu biedrības dibināšanās gadu, kad tika pieñemti šâs biedrības statūti. Latviešu Zobārstu biedrība pastāvēja līdz 40. gadiem (ar pārtraukumu 1. pasaules kara laikā). Pētot biedrības sēžu protokolus, varam secināt, ka tās darbība bija samērā mērḳtiecīga, kaut arī nevarēja izpausties visā pilnībā. Politiskā reakcija cariskajā Krievijā tolaik kavēja vairāku organizāciju, arī minēto zobārstu biedrību, darbību.

Latviešu Zobārstu biedrības pirmās sēdes protokola ierakstu atrodam 1909. gada 11. janvārī. Sēdē piedalījās 8 locek|i. Tajā notika priekšsēdētāja vēlēsanas (par priekšsēdētāju togad un arī turpmāk katru gadu tika ievēlēts Kārlis Barons); tika nolemts atvērt klīniku zobu un mutes dobuma slimību ârstēšanai; pasūtīt 
zobārstniecības žurnālus un iekārtot bibliotēku; parakstît līgumus ar firmām nepieciešamo instrumentu un materiālu iegādei.

Latviešu Zobārstu biedrỉbas darbība nebija sevišķi aktīva: 1909. gadā notika 2 sēdes, 1910. - 3, 1911. - tikai viena, 1912. - 2, 1913. -2, 1914. gadā - viena sēde. Pēc protokoliem var secināt, ka 1909. gadā biedrība iepirka instrumentus un materiālus. 1909. gadā biedrības ietvaros tika nolasītas 2 lekcijas un organizētas 2 jaunas aparatūras demonstrācijas. Piemēram, K. Barons lasīja lekciju par gangrēnas ārstēšanu, demonstrēja rentgenkabinetu, bet E. Hibšmanis stāstīja par silikātcementu (izgatavots viṇa laboratorijā), demonstrējot tā kvalitâti. 1910. gadā lasīti šādi referāti: K. Barons par jaunākiem pētījumiem kariesa etiologijā, E. Hibšmanis par nospiedumiem plastikā, P. Birze par trikrezolformalīnu un Pyorrhoea alveolaris. Par zinātniski profesionālām têmām sapulcēs runāja arī docents Ā. Êrleins (protezē̌̌ana, ortodontija), K. Jannaus (uztura ietekme uz kariesa veidošanos), K.Bumbiers (zoba saknes ârstē̌̌ana) u.c.

1910. gadā Latviešu Zobārstu biedrība un Rīgas Odontologu biedrība izteica vēlmi izstrādāt dažus kopējus noteikumus par abu biedrỉbu loceklu savstarpējām attiecỉbām, kā arī par citiem profesionāliem jautājumiem. Sēdes protokolā (1912. gada 11. februârī) atzīmēts, ka mēginājumi izstrâdầt kopējus noteikumus izrādījās neveiksmīgi, turklāt tiek uzsvêrts, ka vainojama pie tā ir Rīgas Odontologu biedrība.

Latviešu Zobărstu biedrība risināja arī sociālus jautājumus. 1912. gadā Latviešu Zobārstu biedrībā griezầs Izglîtības biedrībã ar lūgumu sniegt zobārstniecisku palīdzību 850 skolēniem. Latviešu Zobārstu biedrība ieteica Izglītības biedrībai ierikot zobārstniecỉbas kabinetu un apsolīja pieṇemt un konsultēt skolēnus bez maksas reizi nedē|ā. Biedrības darbība izbeidzās 1914. gadā.

1. pasaules kara laikā vairākumam zobārstu nebija iespējas nodarboties ar privātpraksi: da|̧a bija iesaukta armijā, da|ai nācās emigrēt. Šajā laikā apsîka jau tã vâjo zobārstu biedrību darbība.

1919. gada janvārī, lielinieku vald̄̄sanas laikā, tika organizēta Latvijas Profesionālā zobārstu savienība, kuras vadībā bija no Maskavas iebraukušie ărsti. Šìs biedrības darbỉba bija diezgan savdabīga - tăs pienākums bija aizsargāt savus biedrus no valdošās patva|as un apgādāt ar pārtiku. Taču par galveno mērḳi tika proklamēta zobārstniecỉbas attīstība, zobărstnieciskās palīdzỉbas organizē̌̉ana un zobārstniecības ambulanču dibināšana skolās. Tomēr šîs idejas netika realizētas. Latvijas Profesionālajā zobārstu savienībā bija ap 200 cilvēku; tajā bija arī zobu tehniḳi un medicīnas mãsas. Sakarã ar to, ka loti liela zobãrstu dala nepaspēja atgriezties no emigrācijas, zobu tehniķu bija tikai ap desmit, bet medmāsu, kas nodarbojās ar stomatologiju, - vēl mazāk. Biedrībā bija samērā daudz cilvēku, kam nebija nekāda sakara ar stomatologiju. Dalẹji tie bija citu profesiju pârstāvji ar dentistu vai stomatologu diplomu, da|ēji - cilvēki, kas strādāja pie dentistiem par palīgiem. Formāli Latvijas Profesionāla zobārstu savienība pastāvēja lĩdz 1922. gada maijam, lai gan tā bija savu nozìmi zaudējusi 1919. gada maijā. 
1919. gada rudenī notiek Bermonta-Avalova karaspēka uzbrukums un lielinieku atkăpšanās. Šajā nenoteiktajā politiskajā situācijā Latvijas Profesionālā zobārstu savienības darbība uz neilgu laiku tiek pãrtraukta. 1920. gadā Latviešu Zobārstu biedrība atkal atsāka savu darbību, kas 30 gados kluva plašāka. Šajā laikā biedru skaits sasniedza jau 90. Sēdēs tiek izskatīti jautājumi par pakalpojumu cenu standartizēŠanu, tiek atzīmēts nepietiekams spējīgu zobu tehniķu skaits. 1920. gada 24. septembra sēdes protokolā rakstīts, ka Latvijā ir 205 zobārsti, no tiem 43 latvieši, 140 ebreji, 15 vācieši, 6 krievi, 1 dānis; 130 ir sievietes; Rīgā reǵistrēti 150 zobārsti.

Drīz pēc darbības atjaunošanas Latviešu Zobārstu biedrība sāk izdot rakstu krājumu. Šajos rakstos rodama informācija gan par zinâtniskām, gan par profesionālām, gan izglîtības têmām. Tā, ārsts K. Jannaus norāda uz zobu slimību ietekmi uz organisma vispārējo stāvokli [11]. Arī citi autori raksta par šīm tểmām, piemēram, A. Bērziña saista košanas aparāta slimības ar infekcijas slimībām, J. Nīmanis - ar rahītu, R. Sniķers - ar adenoīdiem [12, 13, 14, 15].

1920. gada aprīlī tika registrēta Rịgas Odontologu biedrība, kas pēc dažu zinātnieku domām bija tiešs Latvijas Profesionālās zobārstu savienības turpinājums. Tomêr šãda biedrība bija darbojusies no 1905. gada, lai gan izteikti vāciska (Rigaer Odontologischer Verein). Vēlāk nodibinătā Rīgas Odontologu biedrībā 1928. gada bija 88 biedri. Līdz 1929. gadam notika 80 lekcijas un demonstrācijas par profesionāliem odontologijas un zobārstniecỉbas jautājumiem. Latvijă pirmoreiz tiek organizēti zobărstu kursi berlīnieša Dr. Landsbergera vadībā. Šâs biedrības delegāti kopā ar veselības aprūpes departamentu piedalās arī ârstniecības nolikuma izstrādāšanā [16]. 1922. gadā pēc konflikta ar Rīgas Odontologu biedrỉbu, daḷa biedru no tās izstājās un nodibināja jaunu zobārstu biedrību - Rĩgas Zobārstu biedrību, kas registrēta 1922. gada 13. jūnijā [9].

1925. gada septembrī Latvijas I zobārstu kongresā tika nolemts atkal nodibināt zobārstu savienību, kurā ietilptu arī Rĩgas, Liepājas, Jelgavas un citas zobārstu biedrības. 1. decembrī tika apstiprināta Latvijas Profesionālā zobārstu savienība. Sakarā ar to biedru skaits tajā pieauga no 200 līdz 500. Par jaunās biedrības mērḳi k|uva dažădu Latvijas pilsētu zobārstu saskaņota darbība. Par šās biedrības kodolu k|uva Rīgas Zobārstu biedrība, Latviešu Zobārstu biedrība un Rīgas Odontologu biedrỉba. Tās uzdevumi bija šădi:

1) zobārstu reprezentācija dažādās valsts iestādēs - pašvaldỉbās, slimokasēs, arodbiedrībās, tiesā utt. Palīdzība biedriem slēgt līgumus ar augstākminêtām instancēm;

2) aizsargāt ārsta godu un sekot ārsta ētikas normu izpildei. Nodibinăt attiecĩgas komisijas un institūcijas, kā arī noteikt to darbības kārtību;

3) sadarboties ar citām veselības aprūpes organizācijām, attīstīt skolās higiēnu, nodibināt zinātniskas komisijas dažādu profesionālu un zinātnisku jautājumu risināšanai; 
4) aizsargāt biedru materiālās intereses;

5) izstrādāt tarifu samaksu;

6) palīdzēt trūcīgiem un slimiem zobārstiem, dibināt speciālu fondu;

7) organizēt kvalifikācijas celšanas kursus, zobārstu kongresus, speciālus preses izdevumus, stipendiju piešķiršanu, balvu pasniegšanu;

8) sekmēt zobārstu apvienošanos biedrībās.

Latvijas Profesionālās zobārstu savienības materiālo pamatu veido 1) ikgadēja biedru nauda, 2) pe|ṇa no dažādiem pasākumiem, dažādu iestāžu palīdzība, 3) pe|̣na no preses izdevumiem, nekustamā īpašuma [17].

No 2. Latvijas zobārstu biedrïbas sapulces materiāliem var secināt, ka vislabākie rezultăti bija zinātniski profesionālajā jomā: tika organizēti kvalifikācijas celšanas kursi zobārstiem, kā arī realizēta ideja par palīdzību zobārstu profesionalitātes celšanā [18].

Savienībai bija savs preses izdevums - žurnāls Stomatologijas Apskats latviešu, vācu un krievu valodā. Žurnālu izdeva reizi četros mēnešos. Kopumā iznāca 4 numuri 1928. gadā un 4 numuri (3. un 4. apvienoti) 1929. gadā.

Bez minētām Rīgas biedrībām 20.gs. sākumā vēl aktīvi darbojās arī Liepājas Odontologu biedrība un Jelgavas Zobārstu biedrība, kuras, kā jau minēts, arī iesaistījās Latvijas Profesionālajā zobārstu savienībā. Liepājas Odontologu biedrība dibināta 1919. gadā un pastãveēja līdz 1939. gada aprīlim. Jelgavas Zobārstu biedrība pastāvēja no 1925. līdz 1939. gada jūnijam [19].

Praktiski visas zobārstu biedrības izbeidza darboties 1940.gadā, kad Latviju okupēja padomju karaspēks. Dažas biedrības likvidējas pašas 1938. un 1939. gadā (Latvijas Profesionālā zobārstu savienība), citas tika likvidētas 1940. gadā (Rīgas Odontologu biedrỉba, Rīgas Zobārstu biedrība) [9].

\section{Zobārstniecības izglītības attīstība Latvijā}

Zobārstniecības augstākās izglītỉbas pirmsākumi ir saistīti ar Latvijas Universitātes Medicīnas fakultātes dibināšanu. Leo Dolina skola, kas pastāvēja līdz 1914. gadam, gatavoja zobārstus ar vidējo izglītību.

Sākumā universitâtes attīstību ietekmēja gadsimtiem ilgi pastāvošã vâcu hegemonija, bet vēlāk - Krievijas vara. Starp šīm divām varām pastāvēja antagonisms, jo vāciešiem 20.gs. sākumā bija vairākums gan Rīgas domē, gan pašvaldỉbās. Ilgus gadsimtus văcu garīgas dzīves centrs bija Tērbata, kas apvienoja Igaunijas, Vidzemes un Kurzemes vāciešus, izplatot vãcu kultūru arĩ Krievijā. Tāpēc, iestājoties "krievu laikam", Baltijas vācieši ar visiem spēkiem sargāja un stiprināja savu universitāti - hegemonijas stūrakmeni.

Taču Rīga ar lielajām slimnīcām un citām sociālās apdrošināšanas organizācijām bija daudz vairāk piemērota medicīnas fakultātes pastāvēŠanai nekā Tērbata, kur slimnieku skaits nebija liels. Tãpēc 1910. gadā, kad Krievijas valdība paredzēja 
paplašināt Tērbatas universitātes klīnikas, daži krievu medicīnas profesori ierosināja pârcelt medicīnas fakultāti uz Rīgu. Tam pretojās vācu konservatīvas aprindas, kas uzskatīja, ka medicīnas fakultātei varētu sekot citas fakultātes. Līdz ar to Rīgas dome, kur vāciešiem bija vairākums, šo ideju noraidīja [20].

Latvijas Universitātes Medicīnas fakultāte dibināta 1919. gadā, bet zobārstniecības nodạa - 1920. gadā pēc Latviešu Zobārstu biedrības iniciatīvas, jo sākumā zobārstniecība netika iek|auta LU Medicīnas fakultātes mācību programmā.

Apspriežot 1919. gada zobārstniecības stāvokli Latvijā, latviešu zobārsti (Latviešu Zobārstu biedrība) atzīmēja, ka

1) $21 / 2$ gadu ilga zobārstu izglītība pēc Krievijas parauga neatbilst laika prasībām;

2) nav pie|aujams atstāt zobārstniecības mācību iestādes privāto uzṇēmēju rokās;

3) zobārstniecība jāiek|auj Medicīnas fakultātes mācību programmã kā pilntiesīga disciplīna;

4) jālūdz Medicīnas fakultātei gādība par jaunas zobārstu paaudzes apmācību;

5) jāievēl komisija, kurai būtu jâuzdod Medicīnas fakultātei sastādīt attiecīgu memorandu un izstrādāt piecgadīgas mãcību programmas pagaidu projektu.

Medicīnas fakultātes sēdēs Zobārstniecības noda|as darba organizācijai tika veltīta īpaša uzmanība. 1920. gada 7. maijā fakultāte pieñēma mācību programmu zobārstiem, kuru bija izstrādājuši K. Barons, A. Pētersons, P. Birze, E. Sintenis, K. Jannaus. Pirms examen philosophicum topošajiem zobārstiem lekcijas bija jāklausās kopã ar vispārējās plūsmas mediki iem. 5 un 6 . semestrĩ tiem bija jānodarbojas ar protezē̌̌anas tehniku, plastiku, vispārīgo patologijiju un patologisko anatomiju. Studiju ilgums bija 5 gadi $[21,22]$.

Neraugoties uz to, ka Zobårstniecības nodala tika dibināta gandrīz reizē ar Medicīnas fakultāti, tai nebija vadītāja. Turklāt pirmos divus gadus studenti nenodarbojās ar zobārstniecību, jo universitātei šiem mērkiem nebija ne telpu, ne mācībspēku. Studenti klausịjās teorētiskās lekcijas anatomijā, fiziologijā, patologiijā u.c. disciplīnās kopā ar medicīnas studentiem.

1921. gadā par Zobārstniecības nodalas vadītāju tika iecelts dzelzcẹ̣a slimnīcas galvenais ārsts Kārlis Barons, kura pirmais uzdevums bija atrast studijām piemērotas telpas. 1922. gadā par viṇa vietnieku tika iecelts J. Vaivariṇš. Šo divu cilvēku energija un entuziasms arī nostādīja Zobārstniecības studiju nodaḷu "uz kājām". 1922. gadā pēc vairākiem mēginājumiem studijām tika atrastas telpas Stabu ielā 9 . lai gan pagāja vēl pusgads, līdz iepriekšējie iemītnieki telpas atbrīvoja.

Nākamais uzdevums bija nodrošināšana ar inventāru, jo universitātes budžetā līdzek|i šīm vajadzībām netika paredzēti. Aprīkojums maksāja dārgi un tāpēc nācās būt loti taupīgiem, lai sagādātu pašu nepieciešamāko. K. Barons sarunāja ar vienu no Rīgas firmām par Zobārstniecības institūta nodrošināsanu ar inventāru uz 
Pãrskats par slimnieku skaitu un veiktiem darbiem ambulancē

\begin{tabular}{|c|c|c|c|c|c|c|c|c|}
\hline Gads & $\begin{array}{c}\text { Jaunu } \\
\text { slimnieku } \\
\text { skaits }\end{array}$ & Apmeklejumi & Plombas & $\begin{array}{c}\text { Zobu } \\
\text { ekstrakcilas }\end{array}$ & Operäcljas & $\begin{array}{c}\text { Rentgenuz- } \\
\text { oémumi }\end{array}$ & Pârsejumi & Diatermilja \\
\hline $1923 / 24$ & 510 & 5231 & 888 & 161 & 10 & 47 & . & - \\
\hline $1924 / 25$ & 552 & 8054 & 1242 & 155 & 10 & 54 & - & . \\
\hline$1 9 2 5 \longdiv { 2 6 }$ & 522 & 7889 & 986 & 256 & 10 & 211 & - & - \\
\hline $1926 / 27$ & 643 & 9379 & 1856 & 921 & 10 & 192 & 39 &. \\
\hline $1927 / 28$ & 731 & 11924 & 1955 & 777 & 47 & 303 & 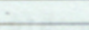 & - \\
\hline $1928 / 29$ & 1064 & 12176 & 2412 & 1232 & 58 & 787 & . & - \\
\hline $1929 / 30$ & 1208 & 15044 & 2625 & 1652 & 135 & 1198 & 323 & - \\
\hline $1930 / 31$ & 1088 & 14717 & 1905 & 1352 & 157 & 656 & 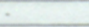 & . \\
\hline $1931 / 32$ & 1093 & 12741 & 1758 & 1033 & 403 & 461 & $\$ 63$ & - \\
\hline $1932 / 33$ & 1258 & 17000 & 2280 & 1173 & 125 & 1038 & 952 & 180 \\
\hline $1933 / 34$ & 1460 & 18006 & 2440 & 1729 & 185 & 1408 & 1075 & 192 \\
\hline $1934 / 35$ & 1322 & 16080 & 2412 & 1889 & 168 & 1397 & 928 & 420 \\
\hline $1935 / 36$. & 1261 & 15906 & 1773 & 1858 & 213 & 1670 & 233 & 315 \\
\hline $1936 / 37$ & 1200 & 15632 & 1732 & 2001 & 267 & 2025 & 956 & 435 \\
\hline $1937 / 38$ & 1242 & 16555 & 2193 & 2678 & 348 & 2344 & 1388 & 598 \\
\hline $1938 / 39$. & 1563 & 17105 & 2064 & 2316 & 499 & 3157 & 1996 & 602 \\
\hline Kopd & 16717 & 213439 & 30581 & 21244 & 2645 & 16948 & 2742 & 8483 \\
\hline
\end{tabular}

kredīta, institūtam maksājot iespēju robežās: cik daudz rēḳins tiks apmaksāts, tik daudz aparatūras paliks institūta īpašumā. Atrodot sādu izeju no situãcijas, K. Barons sagādāja 15 stomatologijas krēslu, rentgenaparātu, laboratorijas un auditorijas aprīkojumu, speciālas şlirces, citus instrumentus. Šajā laikā Finansu Ministrija izsniedza institūtam 1000000 rublu. Tas |ãva apmaksāt iepirkto aparatūru un izremontēt telpas, kas kopsummā izmaksāja 800000 rub|ju.

Măcību plāns bija šāds: anatomija, histologija, fiziologija. k̦īmija, zoolog̀ija, botānika, farmakologija un receptūra, vispārīgā patolog̀ija, patologiskā anatomija. mikrobiolog̉ija, vispārīgā kirurg̀ija, sifiliss un ādas slimības, higiēna, kā arī speciālie priekšmeti - protezēšanas tehnika un dentiatrija. Īpašu uzmanību veltīja praktiskam darbam: zobu ekstrakcijai, zobu sagatavošanai plombēšanai, slimnieku apskatei klīnikā, asistēšanai operācijās, rentgenuznēmumu interpretācijai, mākslīgo zobu izgatavošanai.

Sākumā ar zobārstniecības studentu speciālo apmācību nodarbojās viens docētājs, taču, pieaugot studentu skaitam, radās nepieciešamība palielināt arī mācībspēku skaitu - palielināja gan asistentu, gan palīgpersonāla skaitu. Tehniskās dalas vadīsanai 1925. gadā no Heidelbergas universitātes tika uzaicināts $D r$ : med un $D r$. med. dent. Ādams Êrleins (Oehrlein) kas bija beidzis Vircburgas Universitātes medicīnas fakultāti, strādājis par zobārstu Brēmenē, Štutgartē, Berlīnē, Dortmundē, Vircburgā. 1920. gadā Érlangenes Universitāte piešḳīra vinam Dr. med. dent. zinātnisko grādu. Docenta Êrleina darbība labvēlīgi iespaidoja institūta attīstību: tika virzīti darbi protezēŠanas laboratorijā un ortodontiskajā ambulancẽ. Kad Ā. Êrleins nomira 1935. gadā, vina vietā par lektoru sāka strādāt $D r$ med. Domeniks Kalvelis. 
Pãrskats par klīnikas darbību

\begin{tabular}{|l|l|l|}
\hline Gads & Stacionăra slimnieku skaits & Klinikã pavadìto dienu skaits \\
\hline 1936 & 137 & 1178 \\
\hline 1937 & 230 & 1844 \\
\hline 1938 & 264 & 1526 \\
\hline 1939. lìdz 1.jūl. & 137 & 479 \\
\hline Kopå: & 768 & 5027 \\
\hline
\end{tabular}

Pārskats par mākslīgo zobu un žokḷu regulēšanas nodaḷas darbu no 1923. lĩdz 1939. gadam

\begin{tabular}{|c|c|c|c|c|c|c|c|c|}
\hline \multirow{2}{*}{ Gads } & \multicolumn{2}{|c|}{ Kroni } & \multirow{2}{*}{ Tilti } & \multicolumn{2}{|c|}{ Iznemamás protézes } & \multirow[t]{2}{*}{ Obturatori } & \multirow{2}{*}{$\begin{array}{l}\text { Zokju } \\
\text { I0̂zumu } \\
\text { Sinas }\end{array}$} & \multirow{2}{*}{$\begin{array}{l}\text { Ortodontiski } \\
\text { aparati }\end{array}$} \\
\hline & Metala & Porcelâna & & Metala & Kaučuka & & & \\
\hline $1923 / 24$ & 22 & - & 15 & - & 13 & - & + & - \\
\hline $1924 / 25$. & 55 & . & 32 & - & 20 & . & 4 & - \\
\hline $1925 / 26$ & 29 & - & 42 & 1 & 17 & . & 1 & 1 \\
\hline $1926 . / 27$ & 13 & 3 & 45 & 6 & 11 & - & 4 & 13 \\
\hline $1927 / 28$ & 17 & 4 & 42 & 9 & 12 & 3 & 6 & 27 \\
\hline $1928 / 29$ & 40 & - & 34 & 20 & 10 & 2 & - & 113 \\
\hline $1929 / 30$. & 59 & 1 & 61 & 24 & 47 & 2 & 8 & 142 \\
\hline $1930 / 31$. & 48 & 3 & 53 & 28 & 12 & - & - & 120 \\
\hline $1931 / 32$. & 29 & 5 & 47 & 18 & 7 & . & 5 & 300 \\
\hline $1932 / 33$ & 64 & 9 & 40 & 18 & 42 & 1 & 9 & 200 \\
\hline $1933 / 34$ & 51 & 2 & 33 & 12 & 35 & 1 & 9 & 651 \\
\hline $1934 / 35$ & 105 & 12 & 57 & 18 & 57 & - & 11 & 720 \\
\hline $1935 . / 36$. & 105 & 15 & 29 & 13 & 65 & 2 & 12 & 780 \\
\hline $1936 / 37$ & 147 & 32 & 33 & 41 & 58 & 3 & 37 & 890 \\
\hline $1937 / 38$ & 90 & 42 & 46 & 17 & 58 & 1 & 34 & 883 \\
\hline $1938 / 39$ & 213 & 25 & 51 & 27 & 75 & 3 & 48 & 900 \\
\hline Kopà & 1087 & 153 & 660 & 258 & 539 & 18 & 188 & 5740 \\
\hline
\end{tabular}

Sakarā ar to, ka Zobārstniecības institūtam bija jāsagatavo labi speciālisti, abiturientu atlase bija stingra ne vien zināšanu, bet arī veselības ziñā. Piemēram, ar zobārstniecĩbu nevarēja nodarboties cilvēki, kas nevar korigè̃t savu redzi lielas hipermetropijas vai izteikta astigmatisma dēj, slimo ar tuberkulozi, kam trīc rokas, ir slimi nagi, epilepsija u.tml. Medicīnas fakultāte vairākus gadus iebilda pret šãda veida atlasi un galu galā ar universitātes padomes piekrišanu, to atcēla. Tomêr, sākot ar 1938./39. mācību gadu, šãdu atlasi (ar dažã̄m izmaiṇām) atjaunoja ne tikai Zobārstniecības noda|ā, bet arī visā Medicīnas fakultātē.

Pirmie trīs studiju gadi tika veltīti teorētisko zināšanu apguvei un asistē̌̌anai vecāko kursu studentiem. Līdz ar to Šie studenti varēja iemācīties rakstīt slimības vēsturi, pareizi pasniegt instrumentus, tos sterilizēt, gatavot plombas. Divu vecāko kursu studentiem bija jāpieñem slimnieki, jāstrādā ar modernu aparatūru, jāveic analīzes, jādiagnosticē patologija un arī jāoperē. Beidzot universitāti, zobărstam bija jau jābūt apguvuŠam prasmi operēt, protezēt un sniegt ortodontisku palīizìbu, 
bija jāpārzina konservācijas tehnologija. Pirms eksāmeniem studentam bija jāizstrādā patstāvīgs zinătnisks darbs klīnikā vai ambulancê. Studentiem bija jāzina arī žok|u un mīksto audu slimības, bija jāpiedalās attiecīgajās operācijās, jāseko slimības dinamikai. Šiem nolūkiem institūts 1936. gadā atvēra klīniku ar 8-10 vietām.

Liela uzmanība tika veltìta arī preventīvai medicīnai. Šajā jomā institūts veica propagandiskus darbus žêlsirdīgo māsu un skolotāju vidū, kã arī provinces iestādēs.

Aktīvu palīdzību Zobãrstniecỉbas institūtam sniedza arī Sarkanais Krusts, dāvinot institūtam instrumentus, gultas un velu klīnikai, kã arī solīja 60000 latu jaunu ēku pirkšanai.

Zobārstniecības institūta telpās varēja strādāt 25 studenti no katra kursa, taču dažādu iemeslu dē| kursā uzṇēma vairāk studentu. Līdz ar to vecās êkas institūtam kluva pārāk šauras, 1937. gadā institūts dibina speciālu fondu, lai mēginātu tikt galā ar savâm vajadzībām [28].

Pirmo piecgadīgo mācību programmu 1936. gadã universitātes padome părstrādāja par sešgadīgo, taču 1937. gadā to atcēla un izdeva rîkojumu tomēr ieklauties piecos gados. Zobārstnieciskā apmācība dalījās subspecialitātēs: konservatīvā zobārstniecība, ḳirurgija, protētika, ortodontija, parodontoze. No kopējā priekšmetu skaita zobārstniecĩbai veltīja $60 \%$.

Pati Latvijas universitātes Medicīnas fakultāte pastāvēja līdz 1950. gadam, kad to reorganizēja par Rīgas Medicīnas institūtu (pašreiz Rīgas Stradiṇa Universitāte).

\section{Medicīnas fakultātes Zobārstniecības nodaḷas aspiranti, studenti un absolventi}

\begin{tabular}{|c|c|c|c|c|}
\hline Mâcibas gads & Aspiranti & Uznemti studenti & Studejoso kopskaits & Absolventi \\
\hline $1919 / 1920$. & - & - & - & 12 \\
\hline $1920 / 1921$. & 25 & 17 & $18+2$ hosp & - \\
\hline $1921 / 1922$ & 15 & 15 & 37 & 22 \\
\hline $1922 . / 1923$. & 36 & 24 & $72+1$ brivkl. & - \\
\hline $1923 / 1924$. & 29 & 24 & 81 & - \\
\hline $1924 . / 1925$ & 29 & 24 & 100 & 11 \\
\hline 1925.11926. & 39 & 22 & 114 & 9 \\
\hline $1926 . / 1927$. & 46 & 24 & 141 & 7 \\
\hline $1927 / 1928$. & 58 & 32 & 170 & 28 \\
\hline $1928 . / 1929$. & 56 & 32 & 179 & 13 \\
\hline 1929.11930 & 57 & 28 & 190 & 28 \\
\hline $1930 . / 1931$. & 67 & 39 & 199 & 22 \\
\hline $1931 / 11932$ & 79 & 25 & 205 & 27 \\
\hline $1932 . / 1933$ & 77 & 26 & 199 & 38 \\
\hline $1933 / 1934$ & 86 & 25 & 189 & 34 \\
\hline $1934 / 1935$ & 65 & 23 & 174 & 35 \\
\hline $1935 . / 1936$ & - & - & 138 & 34 \\
\hline $1936 / 1937$ & 63 & 32 & 139 & 21 \\
\hline $1937 / 1938$ & 58 & 22 & 138 & 21 \\
\hline \multirow[t]{2}{*}{$1938 / 1939}$. & 114 & 50 & 170 & 30 \\
\hline & & & Kopa a & 392 \\
\hline
\end{tabular}


1936. gadā tika apstiprināti Zobārstniecības institūta studiju gaitas noteikumi 1937./38.māc. gadam. Tie paredzēja, ka Zobărstniecības institūtā var iestăties tikai tie Medicīnas fakultātes studenti, kas ir beiguši trīs gadu programmas kursus un izturējuši speciālu pẩrbaudi, kas pierāda viṇu spēju strādāt par zobārstu.

Mācību laiks ir 3 gadi jeb 6 semestri. Tas sadalīts 3 posmos:

1. posmā zobārstniecības propedeitikas un higiēnas zināšanu apguve ar praktiskiem darbiem;

2. posmā speciālu klīnisku zobārstniecības priekšmetu apguve ar praktiskiem darbiem ambulancēs;

3. posmā stažěšanās ar praktiskiem darbiem ambulancēs, klīnikā un medicīnas vēsturē.

Pāreja no 1. posma uz otro var notikt pēc tam, kad veikti 1. posma darbi, bet uz trešo - pēc 1. un 2. posmā priekšmetu pilnīgas nokārtošanas.

Gala eksāmeni ir trīs:

1. stomatologijā (dentiatrija un mutes dobuma ķirurgija),

zobu anatomijā,

zobu ekstrakcijā,

zobārstniecības rentgenologijā;

2. protezē̌̌anas tehnikā un metalurgijiā;

3. ortodontijā.

1938. gadā mācību noteikumi tika mainīi: mācỉbu ilgums Zobârstniecỉbas noda|ā 5 gadi. Mācỉbas sadalītas divos posmos: pirmajā ietilpst pirmo 2 mācỉbu gadu priekšmeti, bet otrajā - pēdējo 3 gadu priekšmeti. Pieauga galvenokārt vispārējo medicīnas disciplīnu mācỉbu ilgums (bērnu slimības, nervu slimỉbas, venerologija). Taču arī speciālā zobārstniecỉbas programma tika paplašināta. Bija paredzēti sădi gala eksāmeni:

1. zobărstniecỉbā (dentiartrija, mutes dobuma ḳirurg̀ija, parodontoze, zobu anatomija, zobu ekstrakcijas prasme, zobārstniecỉbas rentgenologija un fizikālā terapija;

2. protezēšanas tehnikã un metalurgijiā;

3. ortodontijā.

\section{Zobārstniecība 20. gs. 20. un 30. gados}

1923. gadā zobārstu skaits sasniedza 491, bet 1928. gadā, sakarā ar Medicīnas fakultātes Zobārstniecības noda|as darbību, tas pieauga līdz 720. Lielākā dạ̣a ârstu (apm. $60 \%$ ) bija koncentrēta Rīgā [3].

Šajā periodā zobārstniecības dienestam bija īpatnējs raksturs: ar to galvenokārt nodarbojās privātprakses ārsti. Šãāa veidā bija loti grūti nodrošināt visu sabiedrību ar zobārstniecības palīdzību, it īpaši laukos. Zināma nozīme bija slimokasēm, pateicoties kurām zobārstniecỉba vietumis tika organizēta ar atlaidēm. 
Zobārstniecỉbas zinātniskie pētijjumi tika veikti Latvijas Universitātē, kā arī zobārstu biedrībās. Nozīmīga loma zobārstniecības attīstībā bija ârstu un zobārstu kongresiem (pirmais notika 1925. gadā). Pirmajā kongresā zobārstniecība vēl netika izdalīta kā atsevišķa disciplīna, taču otrajā kongresā tā ar speciālu rezolūciju tika pielīdzināta citām medicīnas disciplīnām.

Profilaktiskā zobārstniecība bija attīstīta relatīvi vāji. Pateicoties Sarkanā Krusta darbībai, tika organizēti zobārstniecības kabineti galvenokārt bezmaksas palīdzības sniegšanai bērniem. 1922. gadā Rīgā atklāta pirmā zobārstniecības ambulance skolā. 1929. gadā darbojās jau 3 šădas ambulances. Izvirzîjās jautājums par sistemātiskas bērnu mutes dobuma uzraudzỉbas nepieciešamību. K. Barons, būdams Sarkanā Krusta un Veselības aizsardzības atbalsta biedrības priekšsēdētājs, organizēja vairākus skolēnu zobu aizsardzības kabinetus, kurus varam uzskatīt par bērnu profilaktiskās zobārstniecības pirmsākumu.

20. gados liela uzmanība tika pievêrsta orālās sepses problēmai, kurai veltītas vairākas publikācijas medicīnas presē (K. Rudzîtis, P. Stradiṇ̌̌, K. Jannaus, J. Nīmanis, K. Barons, K. Bumbiers, S. Feinmans). Tas viss sekmēja zobāstniecības zinātnisko pētijumu attīstību. Pētījumu pamatproblēma bija kariess, tã etiologìija, patog̀enēze un izplatība. Piemēram, 1928. gadā II. Latvijas ārstu un zobārstu kongresā K. Jannaus norādīja uz slimu zobu nozīmi citu slimību etiolog̉ijā, uz kariesu kā uz sociālu patolog̀iju, uzskatot par nepieciešamu sabiedrībai iesaistîties cīnan ar šo slimību. Šajã sakarā var atzīmēt K. Barona darbu par kariesa etiologijiju un og|hidrātu mainas produktu nozīmi Šajā procesā. K. Jannaus uzskatīja, ka kariesa etiologijāa liela loma ir bāzu deficītam uzturā [24]. Šajā laikā varam atrast arī citu pētniecỉbas virzienu pirmsākumus. Kariesa teorijā īpaša uzmanība tika veltīta plombu materiālam, tā ḳīmiskai iedarbībai uz organismu, pētitas zoba pulpas vitālās amputācijas (E. Hibšmanis, O. Roze) [10], iztirzāti praktiskâs ķirurgiskās zobārstniecības jautājumi (K. Barons, A. Berzners, J. Rencis) [26].

Pēc tam, kad Medicīnas fakultātē pieṇem darbā docentu Êrleinu, sāka attīstîties ortopēdiskā un ortodontiskā zobārstniecība. Tika aplūkoti jautājumi par ortopēdiskās ârstē̌̌anas problēmām plašas ḳirurg̀iskas iejaukšanās gadījumā, no protezēšanās problēmām īpaši izcelta bērnu ortodontija. K. Barons norādīja uz nepieciešamību novērot bērnus zobu maiņas laikā [25].

\section{Latvijas ărstu un zobārstu kongresi}

Ārstu kongresi tika rỉkoti arī agrāk, taču tikai 1925. gadã notikušo kongresu pirmo reizi nosauca par ârstu un zobārstu kongresu. Škiet, ka tieši Šis kongress bija pats nozīmīgākais turpmākai zobārstniecības attīstỉbai (piemēram, pēc tã tika nodibināta Latvijas Profesionālā zobărstu savienība). 


\section{Latvijas ārstu un zobārstu kongress}

III. Latvijas ārstu kongress savā plenārsēdē 1923. gada 8 septembrī pilnvaroja Latvijas Ārstu biedrību sasaukt 1925. gadā IV. Latvijas ărstu kongresu, kas notika 1925. gada septembrī. Pēc K. Barona priekšlikuma piedalīties kongresā tika uzaicināti arī zobārsti, kuru nozīme sabiedrības veselības aizsardzībā ir nenovērtējama. Zobārstniecības sekcijā tika uzklausīti vairāki referāti. Piemēram, K. Goldenbergs runāja par zobu tehniķiem, atzīmējot to zemo kvalifikācijas līmeni, piedāvājot ieviest tehnisku apmãcību zobārstiem, bet tehnikiem kārtot eksāmenu Veselības departamentā. Savukārt V. Gudže savā referātā runāja par Latvijas zobârstu profesionâlās svienības nepieciešamību. Viṇš atzīmēja, ka zobărstu sociālais stāvoklis klūstot aizvien sliktāks, jo vini necīnoties kopā par savu eksistenci. Zobārstu stãvoklis vairākās iestādēs ir daudz sliktāks nekā citu mediḳu stāvoklis, piemēram, algas ziṇā. Tâpēc autors uzskata, ka nepieciešama vadoša instance, kurai uzticētos visi Latvijas zobārsti un kura varētu runāt visu zobārstu vārdā. Šajā organizācijā būtu jāapvieno visas Latvijā esošās zobārstu biedrỉbas. Apspriežot šo jautājumu, zobārstniecības sekcija pilnvaroja sekcijas domi sākt organizēt šādu savienību.

Runājot par bērnu zobārstniecību, K. Jannaus lūdza kongresu pieṇemt vairākas rezolūcijas.

1. Latvijā zobu slimỉbas ir tikpat plaši izplatītas kā citâs valstīs.

2. Kongress pievienojas citu zobārstu kongresu rezolūcijām, piemēram, starptautiskā kongresa rezolūcijai Berlīnē 1909. gadā par to, ka zobu slimībām ir ciešs sakars ar citām slimībām (pirmkārt, ar tuberkulozi), tâpēc zobu slimības jāuzskata par nopietnu starptautisku problēmu.

3. Ar zobu slimībām var cīnīties, organizējot zobārstniecības klīnikas skolâs, kas ir pati nopietnākã un svarīgākā lieta, ieviešot sistemātisku zobu ărstêŠanu kara da|ẫs, izvēršot izglītojošu darbu sabiedrībā, pārliecinot valdību un sadzīves iestādes par masveida zobārstniecības palīdzības sniegšanas nepieciešamību.

4. Kongress atzīst par nepieciešamu dibināt iestādi, kas būtu līdzīga vācu "Das Deutsche Zentralkomitee für Zahnpflege in den Schulen" (Vācu centrālā komiteja zobu kopšanai skolās) un veiktu pãrraudzỉbu par zobu higiểnu skolās.

Rezultātā Zobārstu sekcija pienēma vairākas rezolūcijas.

1. Latvijas zobārstu kongress vērš attiecīgo iestāžu uzmanību uz Zobārstniecības institūta nepilnībām un cer, ka institūts visdrĩzākā laikā tiks apgādāts ar modernu tehniku un mācībspēkiem, lai jaunie zobārsti būtu attiecīgi sagatavoti savam uzdevumam tautas veselỉbas aprūpē.

2. Visi zobārsti, kas dotajā brīdī strādā zobārstniecībā un ieguvuši diplomus Krievijā līdz 1918. gada 18. novembrim, tiek atzìti par vienlīdzigiem ar Latvijas Universitātes absolventiem. 
3. Kongress atzīst par nepieciešamu reprezentēt savu pārstāvi Veselības departamentā, tāpat kā ārsti, farmaceiti un veterināri.

4. Sakarā ar to, ka no zobu kariesa valstī cieš vairāk nekā $95 \%$ iedzīvotāju, nepieciešams organizēt zobārstniecisku palīdzību skolās, klīnikās, slimnīcās, sanatorijās, bērnu namos, cietumos.

5. Kongress nolemj zobārstu interešu aizsardzībai (zobārstu profesija, vispārīgie zobārstniecỉbas jautājumi) dibināt zobārstu kameru, kurai būtu jādarbojas uz valdības atbalstīta statusa pamata.

6. Līdz brīdim, kamēr kamera tiks nodibināta, steidzami izveidot Latvijas Profesionālo zobārstu savienību minēto jautājumu realizēšanai dzīvē.

7. Kongress konstatē, ka slimokases Latvijā ir nepieciešamas, taču tâs ir jāmaina, jo tās nes maz labuma tautai, bet ārstiem pat kaitē. Sakarā ar to kongress piedāvã:

a) brīvu ārstējošã ârsta izvēli;

b) brīvu izvēli arī slimokasēs, kam ir savas stomatologiskās klīnikas;

c) zobārstu atalgojumu atkarībā no darba stāža;

d) no slimokases līdzekju atlikuma atbalstīt tos zobārstus, kam tas ir nepieciěsams;

e) pieṇemt zobārstus kasu vadīiōa;

f) regulēt kasu dalībnieku skaitu: tos, kam ienākumi pārsniedz 4000 latu gadā, nepieñemt;

g) organizēt pensijas fondu gan no ikgadējiem slimokasu ienākumiem, gan arī no valdības subsīdijām [26].

II. Latvijas ārstu un zobārstu kongress notika 1928. gadā. Zobārstniecíbas sekcijā tika nolasīti sādi zinātniski referāti[28]:

Der normall und pathologischen Zahn im Röntgenbilde (prof. E. Vēbers) Moderne zahnärztliche Prothetik (privātdoc. A. Êrleins);

Medikamentu ietekme uz zoba pulpu un apkakli (L. Veibele);

Pulpas devitalizācija un ekstirpācija (O. Roze);

Zoba saknes sterilizăcija (E. Hibšmanis).

III. Latvijas ārstu un zobārstu kongress notika 1932. gadā. Zobārstniecības sekcijā tika nolasīti šãdi referāti[29]:

Žokja defektu un lūzumu ārstēšana (Ā. Ērleins);

Košanas aparăts un zīdaiṇu barošana (K. Barons);

Košłā̄̌sanas aparăts un adenoīdi (R. Sniķers);

Koš|āšanas aparăts un žok|u anomālijas ( $\bar{A}$. Êrleins). 


\section{Zobārstu tiesiskais statuss}

Valsts līmenī zobārstu tiesības noteica un nostiprināja ārstu likums, kas stājās spēkã 1938. gadā. Attiecībā par zobārstiem sajā likumā tika apmierinătas visas II. Latvijas ārstu kongresā izvirzìtas prasības. Tas ir saprotams, jo likuma izstrādẽ piedalījās arī zobārsti (K. Barons u.c.). Tomēr jāatzīmē, ka no prasību izvirzīšanas līdz to apmierināšanai pagāja 10 gadu.

Līdz tam zobārstu tiesisko statusu Latvijā noteica gadījuma raksti no Krievijas impērijas "likumu krājuma" [27]. Šie likumi bija visai nenoteikti. Par zobārstu tiesībām, stājoties valsts vai sabiedrības dienestā, tika noklusēts, tāpat kā par vinuu attiecībām ar karaklausību. Zobārstniecības prakses tiesības netika ierobežotas ar attiecīgiem likumiem, tās varēja izmantot katrs. Tāpēc Latvijas Profesionālā zobārstu savienība izstrādāja īsu likumu (divi panti), kura mērķis bija aizsargāt zobārstniecības praksi no cilvēkiem, kam uz to nav tiesību. Apspriežot šo likumprojektu Veselības departamentā, izrādījās, ka administrācija vêl nav atbrīvojusies no veciem uzskatiem par zobārstiem kā par otrās kategorijas ārstiem, līdz ar to likumprojektam tika pievienoti vêl divi papildu panti: viens, kam bija jāatjauno ārstu valdes uzraudzība pār zobārstniecības kabinetu atvēršanas kārtību un protēžu izgatavošanā izmantoto metālu kvalitāti; otrs - paredzēja stingri noteikt un ierobežot zāles, ko zobārsti drīkst parakstīt sev un slimniekiem. Latvijas Zobārstu savienība izteicās kategoriski pret šīm izmain̄ām un projekts netika īstenots. Vienlaikus Labklājības ministrijai tika iesniegts lūgums par zobārstu valsts dienesta tiesību pielīdzinā̌̌anu personâm, kas ir ieguvušas augstāko izglĩtību. Savienība norādīja uz to, ka cariskās Krievijas laikā zobārsti pēc amata klases bija pielīdzināti ārstiem, veterināriem un provizoriem, toties tagad tie stipri atškiras no tiem pēc dienesta kategorijas. Uz to Ministrija atbildēja, ka nevar izpildīt šo lūgumu, jo pastāv dažādas zobārstu kategorijas - dentisti, zobārsti un zobu slimību ārsti. Turklāt departaments Šaubās, vai pat pēdējā grupa (kura, starp citu, iegūst izglītību universitātē) pielīdzināma personām, kuras ir ieguvušas augstāko izglītību. Kara sanitārajā pārvaldē ierosināja jautājumu par zobārstu karaklausību savā specialitātē, kã tas ir ar likumu paredzēts ārstiem un farmaceitiem.

Visas šīs problēmas tika apspriestas II. Latvijas ārstu un zobārstu kongresā. Atspogulojot tã laika situāciju, zobārstniecības sekcija pienēma šãdas rezolūcijas [28]:

1) visām Latvijā praktizējošo zobārstu kategorijām ir vienādas tiesības;

2) ar zobārstniecību drīkst nodarboties tikai tās personas, kam ir attiecīgs valsts diploms;

3) ārstiem, kas vēlas nodarboties ar zobārstniecības praksi, ir vēl jāmācās papildu kursos un jānokārto attiecīgi eksāmeni;

4) zobārstiem ir tiesības parakstīt aptiekãs visus medikamentus, kas nepieciešami zobārstniecības praksē gan sev, gan pacientiem; 
5) zobārstiem iestājoties valsts dienestā, viṇi tiek ieskaitīti vienā kategorijā ar ārstiem, veterinārārstiem un provizoriem;

6) gan miera, gan arī kara laikā zobārsti dienē karaspēkos savā specialitātē kã sanitārā dienesta virsnieki.

Pašãs 1937. gada beigās Latvijas Ministru Kabinets pienēma un Valsts Prezidents ratificēja Ārstu likumu.

Attiecībā uz zobārstiem likums paredzēja:

1) tiesības ārstēt zobu slimības un to komplikācijas ir tikai personām, kas ir beigušas Latvijas Universitātes Medicīnas fakultāti un ir registrētas Veselības departamentā. Tādas pašas tiesības ir iepriekš reg̀istrētiem zobårstiem (20,-30. gados Latvijā vēl nebija ārstu, kas bija ieguvuši izglītību Latvijā). Registrētiem dentistiem ir tiesības nodarboties ar zobārstniecību, taču komplikāciju gadījumā slimnieki jāsūta pie zobārsta. Visiem zobārstiem ir tiesības parakstīt zāles no aptiekas, kas ir nepieciešamas zobu slimību årstē̌̉anai; dentistiem šādu tiesību nav;

2) mākslīgo zobu, protēžu un regulējošo aparātu izgatavošanai drỉkst izmantot tikai zeltu, platīnu vai nerūsējošo tēraudu. Citus materiālus drīkst izmantot tikai ar Veselības departamenta īpašu aṭauju;

3) zobu tehniķiem ir tiesības izgatavot, pārtaisīt un labot mākslīgos zobus un ortodontiskos aparātus tikai ar zobārsta vai dentista at|auju. Zobu tehniķiem ir aizliegts pienemt slimniekus. [14]

\section{Bērnu zobārstniecības attīstība Latvijã}

Bērnu zobārstniecība sāka attīstīties relatīvi agri, jo zobārsti pareizi novērtēja bērnu mutes dobuma sanācijas nozīmi. Taču sistemātiska zobārstniecības palīdzība bērniem netika sniegta līdzek|u un organizācijas trūkuma dēḷ.

19. gs. sākumā bērnu zobārstniecībai bija atsevišku mēginājumu raksturs sakarā ar dažu zobārstu un sabiedrisku organizāciju iniciatĩvu. Piemēram, 1912. gadā Latviešu Zobārstu biedrība piedāvāja atvêrt Rīgā zobārstniecības kabinetu skolēniem, bet Valmierā 1919. gadā. zobu sanācijas pasākumus skolēniem uzsāka J. Vigdorčiks. Pirmais bezmaksas kabinets skolēniem tika atklāts 1922. gadā Rīgā. Vēlāk Skolēnu higiēnas pilsētas noda|ja atklāja vēl dažus kabinetus. Sarkanais Krusts pirmo zobārstniecības kabinetu atklāja 1927. gadā Tukumā. No 1930. gada, kad par Sarkanā Krusta priekšsēdētāju kJuva K. Barons, šādu punktu skaits pieauga un 1938. gadā tas sasniedza 64.

Pirmoreiz plānveida sanācija tika veikta 1931. gadā Ikšksilē un Grīvā. Par tấs nepieciešamību tika runāts 1925. gadã I. Latvijas ârstu un zobărstu kongresā [30].

Bērnu zobãrstniecības galvenais balsts bija K. Barons. Kā Sarkanā Krusta priekšsēdētājam viṇam bija gan iespējas, gan interese attīstīt šo zobārstniecības virzienu. 
Liela nozīme bija K. Barona grāmatai "Zobārstniecības palïdzība pirmsskolas vecuma bērniem", kurā galvenā uzmanība tika veltīta preventīvai medicînai. Šajā grāmatā var atrast arī interesantu statistiku par to, kādi darbi tika veikti zobārstniecíbas kabinetos 1935 - 1937. gadā [25]:

\begin{tabular}{|c|c|c|c|c|c|c|c|c|c|}
\hline \multirow{3}{*}{ Gads } & \multirow{3}{*}{$\begin{array}{c}\text { Mutes } \\
\text { dobuma } \\
\text { apskate } \\
\text { (personu } \\
\text { skaits) }\end{array}$} & \multirow{3}{*}{$\begin{array}{c}\text { Zobu } \\
\text { tirisana } \\
\text { (personu } \\
\text { skaits) }\end{array}$} & \multicolumn{4}{|c|}{ Plombu skaits } & \multirow{3}{*}{$\begin{array}{c}\text { Zobu } \\
\text { regulésana }\end{array}$} & \multicolumn{2}{|c|}{ Zobu ekstrakcija } \\
\hline & & & & & & & & Piena & Permantie \\
\hline & & & Cementa & Amalgamas & Sintêtiskas & Porcelâna & & zobi & zobi \\
\hline 1935 & 4421 & 504 & 1782 & 6919 & . & . & 34 & 3063 & 1213 \\
\hline 1936 & 5601 & 387 & 2780 & 10170 & 506 & 56 & 39 & 4172 & 1462 \\
\hline 1937 & 7326 & 455 & 3052 & 12360 & 581 & 138 & 29 & 5110 & 1778 \\
\hline
\end{tabular}

30. gados skolēnu zobārstniecībā aktīvi darbojās arī citi zobārsti. Skolu kabinetus Rīgā vadīja M. Kilbloka, tajos strādāja L. Veibele-Jakovjeva, E. Kazaka, A. Saiva u.c. Par pareizu zobu attīstību bērniem Latviešu zobārstu biedrības žurnālos rakstīja K. Barons un Ā. Êrleins.

Pēc Otrā pasaules kara Rīgā bija saglabājušies tikai 10 skolu zobārstniecības kabinetu un 6 speciālisti - M. Kilbloka, A. Karlsone, E. Podiṇa, E. Putniṇa, A. Saiva un M. Treimane, taču jau 1945. gadā darbību atjaunoja 27 skolu kabineti [30].

1951. gadā Rīgā tika nodibināta pirmā bērnu stomatologiskā poliklīnika ar 4 štata vietâm terapeitiskajā un vienu vietu ķirurgiiskajā stomatologijā. 1953. gadā tika atklātas rentgenolog̉ijas un ortodontijas nodala. 1966.g. bija jau 52 štata vietas un 116 kabinetu. Liepājā bērnu stomatologiskais kabinets tika nodibināts 1945. gadā. Sākumā tajā strādāja 2, bet no 1964. gada - 4 ârsti. Jelgavā pirmais kabinets tika atklāts 1951. gadā, bet Ventspilī un Daugavpilī - 1945. gadā [31]. 1961. gadā Republikas apvienotajā stomatologijas poliklīnikā atklāja bērnu nodalu, kurā strādāja 6 ârsti.

Skolēnu plānveida sanāciju uzsāka 1955. gadā. Galvenā uzmanība tika pievềrsta cīnai ar kariesu un parodontozes agrīnai diagnostikai. 1967. gadā Latvijā strādāja jau 24 bērnu ortodonti. Darbu vadīja prof. D. Kalvelis, Z. Širaka u.c. [30] Liela nozīme bija arī Latvijas Stomatologu biedrỉbas sapulcēm, kurās tika apspriesti jautājumi par kariesa izplatîbu (A. Saiva, L. Treimane u.c.), par fluora daudzumu dzeramajā ūdenī un zobu fluorizāciju (G. Vigdorčika, A. Saiva, V. Vigdorčiks, L. Treimane). Fluora daudzums dzeramajā ūdenī, it īpaši Rĩgā, bija nepietiekams, un ar to saistīja tik lielu zobu slimību izplatību (G. Vigdorčika, L. Treimane). Uzmanība tika veltîta arī bērnu ķirurg̀iskajai stomatologijai, iedzimtām anomālijām un traumatologijai (I. Bākulis, A. Skag̀ers).

Zinātniskie darbi veltīti galvenokārt kariesa problēmai: pētīta kariesa izplatība un intensitāte, izstrādāti darbi par uztura un citu vides faktoru ietekmi uz kariesa attīstību. Uzmanība pievērsta arī dentogēno fokālo infekciju profilaksei, it īpaši bērniem un reimatisma slimniekiem. Daudzi darbi veltiti parodontozes un mutes dobuma glotãdas slimību agrīnai diagnostikai, profilaksei un ārstēšanai [32]. 
Nozīme bija arī plānveida sanācijas organizēšanai un pieredzes apmaiṇai [33]. 1970. gadā kariozi zobi konstatēti 86-96,4\% skolēnu (kariesa intensitāte bija 2,1-4,7 zobi uz vienu skolēnu). 1948. gadā kariesa intensitâte uz katru Latvijas iedzīvotāju bija 0,6, bet 1968. gadā - 1,4 pilsētas un 1 lauku iedzìvotājiem [34].

\section{Kịurg̀iskās stomatolog̀ijas attīstība}

Atšķirỉbā no citâm zobârstniecỉbas pamatdisciplīnām - terapeitiskās un ortopēdiskās, kas attīstijāas samērā patstâvīgi, - kịurg̀iskā stomatologija vēsturiski veidojās kã vis-

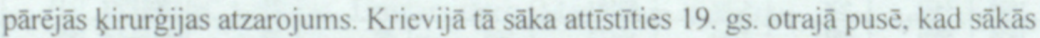

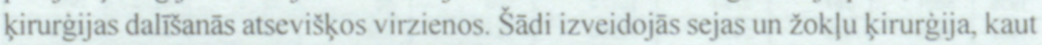
gan seju operēja arī vispārējie ķirurgi (Pirogovs, Djakonovs u.c.) [35].

Latvijā 19. gs. sākumā, kad zobārstniecība vēl nebija izveidojusies par atsevišḳu disciplīnu, ar ķirurg̉isko stomotolog̀iju nodarbojās kirurgi, kas pārsvarā veica žoklu operācijas traumu gadījumā. Savukārt zobārsti veica sīkas operācijas - zobu ekstrakciju, gingivektomiju, cistektomiju.

Par kirurgiskās zobārstniecības attīstības sākumu var uzskatīt Latvijas Universitātes Medicīnas fakultătes Zobārstniecības institūta dibināšanu. Faktiski šis institūts bija poliklīnikas tipa ârstniecības iestāde. Šeit bija arī ḳirurğijas kabinets - pirmã vieta, kurā mutes dobuma ḳirurgiskas slimības gadījumā tika sniegta kvalificēta palīdzība. Tomẽr palīdzības apjoms aprobežojās ar ambulatoriskām operâ̄cijām zobu ekstrakcijām, nelielu labdabīgu audzēju izgriešanu, virspusējo sastrutojumu incĩzijām. Nopietnākâm operācijām slimnieki bija jāievieto stacionārā, taču tăda nebija.

Pirmais stacionārs pềc K. Barona iniciatīvas atvērts 1936. gadā institūta ietvaros. Tajā varêja uznememt 10-12 slimnieku. Klīnikā ârstēja tikai ķirurg̉iskās slimības, kas saistītas ar zobu sistēmu - zobu cistas, žok|a lūzumus, mutes dobuma un sejas iekaisumus. Nopietnākas operācijas - iedzimtu un iegūtu defektu, kā arī deformāciju vai audzēju operācijas izdarīja vispārēja profila ḳirurgi bez šauras specializācijas sejas žoklu ķirurg̉ijā [36]. Ārpus institūta - slimokasu kabinetos, ambulancēs un privātā kārtā - veica tikai zobu ekstrakcijas. İpaši sarežgīitas operācijas līdz 2. pasaules karam netika veiktas arī institūtā.

Pẽc kara klīnikai pieškịira jaunas telpas, kur varēja stacionēt 25 slimniekus, pēc dažiem gadiem vietu skaits pieauga līdz 50. 1936. gadā klīnikā ambulatoriski ārstējās 137 slimnieki, 1946. gadā - 209, 1956. - 726, bet 1966. gadā - 1173 slimnieki. Arī pašreiz saglabājas tendence, vairākumu operāciju izdarīt ambulatoriski.

Kopš 1962. gada, kad par Rīgas Medicīnas institûta Ķirurgiskãs stomatolog̉ijas katedras vadītāju kluva I. Bākulis, sāka attīstīties bêrnu ḳirurgiskã stomatologijja. Zinātnisko darbu ḳirurgiskajā stomatologijā strādāja galvenokārt institūta katedras pasniedzēji un Republikāniskās Stomatologiskās poliklīnikas ḳirurgisko un klīnisko nodalu ărsti. Šiem darbiem bija galvenokārt klīniski morfologisks raksturs ar prak- 
tisku nozīmi:1) sejas un žokł̣a plastiskās operācijas (I. Bākulis, B. Barkāne), 2) iekaisumu ārstēsana (V. Balode, V. Būmeistere), 3) audzēju ārstē̌̌ana (E. Kìmele, M. Vasule) un 4) dažu medikamentu izmantošana (A. Lināre, V. Būmeistere u.c.) [31].

\section{Terapeitiskās un protētiskās zobārstniecības attīstība}

Terapeitiskā zobārstniecība Latvijā ilgi saglabāja saistību ar kirurg̉isko zobārstniecību. Šo divu apakšnozaru krasa atdalīšanās notika 40. gados.

Terapeitiskajā stomatologijā ir atzīmējami vairāki virzieni [31]: 1) cieto audu nekariozas slimības, kariess un tā komplikācijas (atgādināsim, ka kariesa izplatība Latvijā bija $85-95 \%$, intensitāte $-4,0$, reimatisma gadījumā - 7,0 (A. Saiva); fluora saturs Rīgas dzeramajā ūdenī bija $0,08-0,12 \mathrm{mg} / \mathrm{l}) ; 2$ ) parodontopātijas, kas Skolēniem sastopamas $10 \%$ gadījumos; pētījumi tika veikti terapeitiskās stomatologiijas katedrā M. Krauklītes vadībā [37]; 3) mutes dobuma glotādas slimības; 4) bērnu stomatolog̀ija.

Protêtiskă stomatologija săka attīstīies viena no pēdējām (30. gados Zobārstniecības institūtā tika izgatavotas tikai dažas protēzes). Pirmajos pēckara gados (40. gadi) katrā poliklīnikā izgatavoja tikai dažus simtus protēžu gadā, vēlāk šis skaits pieauga un 50. gados protētiskā stomatologiiskā palīdzỉba kvantitatīvi kluva apmierinoša [11, 40]. Cilvēku skaits ar protēzēm uz 10000 iedzīvotāju turpināja pieaugt [31]: 1945. gadā tas bija 37,2; 1950. -69,0;1955. - 172.3; 1960. - 251,3; 1966. gadā-323,5.

Pirmskara gados zobu tehniḳi nodarbojās ne tikai ar protēžu izgatavošanu, bet arī ar pacientu pieṇemšanu. Îstā zobu tehniķu izglîtīiba sākās 1945. gadā, kad Rīgas feldšeru skolā organizēja zobu tehniķu nodą̣u, kas 1947. gadā k|uva par patstāvīgu skolu. 1945. gadā uz 10000 iedzīvotāju bija 0,08 ārstu protêzistu un 0,15 zobu tehniķu, bet 1966. gadā attiecīgi - 0,63 un 1,42 [31].

\section{Ortodontiskās zobārstniecības attīstība Latvijā}

Latvijas ortodontiskās stomatologijas pirmsākumi saistāmi ar prof. K. Barona darbỉbu. Iespējams, ka viṇš pasniedza šo priekšmetu vēl docējot Leo Dolina skolā (1902-1914). Ar prof. K. Barona vārdu saistīta arī augšžokla ekspansijas aparāta konstruēšana. Profesors izprata ortodontijas nozīmi sabiedrībā ne tikai no veselības, bet arī no estētiskā aspekta. Kopš seniem laikiem zobu un žok|u anomālijas latviešu tauta uzskatîja par lielu cilvēka trūkumu [39]. K. Barons nosprauda uzdevumu novērot žoklu attīstību 3-8 gadu veciem bērniem, lai konstatēto anomāliju agrīni likvidētu. Jau 20. gados Zobārstniecības institūta speciālisti atzīmējuši, ka sašaurināts augšžoklis bieži k|ūst par iemeslu augšējo elpce|u hroniskiem iekaisuma procesiem. Latvijā tas tiek novērots it īpaši bieži sakarā ar mitro piejūras klimatu.

Intensīvāk ortodontija sāka attīstīties līdz ar docenta $\bar{A}$. Êrleina atbraukšanu uz Rīgu. No 1925. gada, strādājot Latvijas Universitātes Stomatolog̉ijas institūtā, vị̂š̌ vadīja ortopēdisko stomatologiju. 1935. gadā, pēc docenta Â. Êrleina nāves, par 
Zobărstniecỉbas institūta protētikas un ortodontijas noda|as (vêlāk to nosauca par Ortopēdiskās stomatologijas katedru) vadītāju kluva D. Kalvelis, kas daudz laika veltịja teorētiskam un eksperimentālam darbam. D. Kalvelis izstrādāja anomāliju klasifikāciju un diagnostikas sistēmu, organizēja anomālijām veltītu pētniecisku darbu (1967. gadā stomatologisku anomāliju bija 54,6\% bērnu).

Tātad no pašiem sākumiem ortodontiskais darbs tika sistematizēts diagnostikas un ărstēšanas ziṇā. Par to liecina arī arhĩva dati par ortodontijas kontroles modejiem (uzsākts 1929. gadā, tagad to ir vairāk ne kā 15 000).

Praktisko ortodontisko palīdzỉbu sniedza galvenokārt Ortopēdiskās stomatolog̉ijas katedras darbinieki [40]. No 1944. gada ortodontisko palīdzību sniedza arī Republikāniskās Stomatologiskās poliklīnikas Ortopēdijas noda|as ầrsti. 1953. gadā darbu uzsāk arī Ortodontijas noda|a Rīgas Bērnu stomatologiskajā poliklīnikā, kur ārstu ortodontu un tehniķu skaits pakāpeniski pieauga.

Tajā laikā ortodontiskai palīdzībai Latvijā bija divas formas: centralizēta un da|ēeji decentralizēta, kur ortodonta darbu veica arī liels bērnu stomatologu skaits. No 1923. līdz 1966. gadam Ortopēdiskās stomatologijas katedrā kopā ar Republikānisko Stomatologisko poliklīniku tika sniegta plīdzỉba 15557 slimniekiem. Bērnu stomatologiskajā poliklīnikā ārstēti 13765 bērni, bet 12 Latvijas rajonu stomatologiskajos kabinetos 1966. gadā ārstēšana uzsākta 2237 bērniem.

Zinātniskie darbi tika veikti vairākos pamatvirzienos: ortodontisko anomāliju diagnostika un racionālu ārstē̌̌anas metožu izstrāde. Košanas kustību attīstības biomorfologiskie pētījumi normā un patologijā, kā arī audu izmainas, pielietojot dažâdas ortodontiskâs ārstēšanas metodes; ortodontiskâs palīdzỉbas organizācijas pamati [31]. 90. gados ortodontijas attīstības tempi Latvijā palēninājầs. Zinātnisko darbu veica tikai daži ārsti. Tie bija darbi par ortodontisko anomāliju izplatību, cilvēku attieksmi pret tẩm no estētiska aspekta. Eksperimentālie un morfolog̉iskie pētijjumi tika apturēti līdzeklu trūkuma dē|̣. Bērniem praktiskā ortodontiskā palīdzỉba tika sniegta par brīvu, taču ârstniecisko iestãžu ierobežotie līdzek|i ne|āva izvêrst šo darbu pietiekami plaši.

\section{Zobārstniecība pẽckara gados}

Kara laikā sabiedrības nodrošinājums ar stomatolog̉isko palīdzību bija pilnīgi sagrauts. 1944. gada beigās Latvijas teritorijā bija tikai 102 stomatologiska profila ārsti, stomatologiskās iestãdes palika bez materiāliem un medikamentiem, daudzviet arī bez aprīkojuma. 1945. gadā bija 178 ârstu, no tiem 139 pilsētās. Tãpēc pirmais uzdevums bija âtri papildināt personālu. 1944. gada beigās īsā laikā izdevãs nokomplektēt Medicīnas fakultātes Stomatologijas noda|as 1. kursu, kurã uznēema 64 studentus [41]. No 1944. līdz 1950. gadam Medicinas fakultāti absolvēja 170 jauni stomatologi.

1950. gadā Rīgas Medicīnas institūtā nodibināja atsevišḳu Stomatologijas fakultāti, kuras pirmajā kursā uznēma 25-30 studentu, vēlāk - 50-60. 
1944. gadā stomatologiskām disciplīnām tika veltīti $18 \%$ mācību laika, pārējais fundamentālām zinātnēm un vispārējiem medicīnas priekšmetiem. No 1976. gada stomatologijai tika veltīti $26 \%$, bet 1987 . gadā - 32\% studiju laika. Šâdi sagatavoti ārsti varēja strầāt par vispārējās prakses ārstiem un par ḳirurgiem armijā, taču kā stomatologi tie nebija sagatavoti pietiekami labi.

90. gados stomatologiskām disciplīnām tika veltīi $60 \%$ mācību laika, tiek uzsāktas mācības orālajā biolog̉ijā un patologiijā [42]. Zobārstu intensīvas sagatavošanas rezultātā 60. gados uz 10000 iedzĩvotājiem bija jau vairāk nekā 5 ârsti [43].

Par pamatuzdevumu tika uzskatīta bērnu un kaitīgo profesiju strādnieku mutes dobuma plānveida sanācija. Bērnu plānveida sanācijas programma tika îstenota 1959. gadā. Līdz tam tā bija veikta tikai skolās, kur bija stomatologiskie kabineti.

Pēckara gados rỉkotas arī vairākas republikāniskās konferences, kas bija veltītas dažādām problēmām stomatologijijā (1951., 1954., 1957., 1960., 1964., 1968., 1972. un 1984. gadā).

Latvijas PSR republikāniskajā stomatologiskajā konferencē 1951. gadā atzīmēti vairāki fakti.

1. Zobu ārstēŠana tiek veikta skolu zobārstu kabinetos un pilsētas poliklīnikās.

2. Skolu stomatologisko kabinetu skaits ir pieaudzis līdz 30-40, kas ir daudz vairāk nekā 1944, gadā [10].

3. Sakarā ar plānveida sanāciju un 1948. gadā uzsākto zobu fluorizāciju skolēnu skaits ar karioziem zobiem samazinājies no 86 līdz 67 procentiem.

4. Nepieciešams paplašināt stomatologiiskās palīdzības sniegšanu skolēniem, palielināt ārstu skaitu, lai uz katru ārstu būtu maksimāli 2000-2500 skolēnu.

Saistībā ar kariesu tika atzīmēts, ka

1) kariesa etiologija lídz šim nav izzināta;

2) tiek pētìta cieto audu un emaljas nozīme šajā patologijā;

3) kariesa attīstībā bez eksogēniem faktoriem svarīgi ir arī endogēnie faktori;

4) kariesa profilaksē nozīme ir zobu fluorizācijai;

5) jāizstrādā mācība par racionālu diētu.

Papildu tika apspriesti jautājumi par parodontozes ārstēšanu, žok|u traumatisko osteomielītu u.c.

1960. gada konferencē par zobu slimību pētîjumiem bērniem tika atzīmēts, ka bojāti zobi ir $78 \%$ bērnu vecumā no 3 līdz 7 gadiem, bet bērniem no 7 līdz 18 gadu vecumam zobi ir bojāti $91,8 \%$ gadījumu. Galvenais iemesls ir novēlota zobu ārstēšana, tāpēc bērniem bieži rodas dentogēnas infekcijas.

Piektã republikāniska konference 1964. gadā bija veltīta mutes dobuma plānveida sanācijas organizēšanas jautājumiem un parodontozei. 
Sestajā konference 1968. gadā analizēti pirmie rezultãti un spriests par bērnu plānveida sanācijas paplašināšanu. Sanācijā iek|auta ne vien zobu kariesa agrīna ârstēšana, bet arī parodonta slimību un zobu un žok|u anomāliju ârstēšana [44]. 1966. gadā konstatēts, ka sanēti ir $85 \%$ bērnu pilsētās un $70-85 \%$ bērnu vairumā rajonu. Latvijas zobārstniecības biedrība tika no jauna dibināta 1946. gadā, kad iniciatoru grupa prof. D. Kalve|a vadībā sasauca Latvijas stomatologu sapulci. Tajā pašã gadā tika ievēlēta biedrības valde ar profesoru D. Kalveli priekšgalā. Turpmāk sēdes notika ik mēnesi. Šì biedrība organizēja visas republikas konferences. 80. gados biedrību nosauca par Latvijas Stomatologu zinātnisko biedrību; tajā bija iesaistījušies $70 \%$ visu Latvijas zobārstu [45]. Līdz 1979. gadam par biedrības priekšsēdētāju tika ievēlēts profesors D. Kalvelis, pēc tam - profesors G. Pakalns, savukārt D. Kalvelis tika ievēlēts par biedrības gada priekšsēdētāju. Biedrībā izveidotas vairākas komisijas, kas darbojās dažādos virzienos: gan zinātnes sasniegumu ieviešanā, gan medicīnas zināšanu popularizēšanā, gan medicīnas vēsturē. Biedrība sadarbojās arī ar citu nozaru speciālistiem. Piemēram, atsaucoties uz profesora K. Rudzīša izvirzīto teoriju par fokālo infekciju, tika veikti detalizēti pētījumi (M. Krauklīte, V. Būmeistere, V. Auliks, A. Zviedre, S. Vītola).

\section{Stomatologijas stãvoklis 20.gs. 80.-90. gados}

1989. gadā kariess un parodontoze tika novēroti attiecīgi $38 \%$ un $86 \%$ iedzīvotāju. Intensitāte pẽc KP indeksa (kariozie un plombētie) pieaugušajiem 16-27 gadu vecumā un divpadsmitgadīgiem skolēniem bija 6,7. Zobārsti akcentē, ka sociāli un ekonomiski izdevīgāk ir izmantot profilaktiskās stomatolog̉ijas iespējas. Tāpēc uzmanība tika veltīta arī tādiem faktoriem, kā nepareizs uzturs, nepietiekama mutes dobuma higiēna, nepietiekams fluora daudzums dzeramajā ūdenī. Kopš 1985. gada Latvijā uzsākta profilaktiskās programmas îstenošana bērnu kolektīvos.

Kopējais stomatologu skaits 1989. gadā ir 1413 jeb 5,3 uz 1000 iedzīvotāju (no tiem 4,3 ir ārstnieciski profilaktiskajā darbā, 1,0 ortopēdiskajā darbā, tādējādi kvantitatīvi Latvija bija pirmo 8 valstu starpā).

Vēl arvien trūka stomatologiisko medmāsu, zobu higiēnistu un cita palīgpersonāla. Nodrošinājums ar vidējo medicīnas personālu 1988. gadā ir 60-70\%, tāpēc ārsti $25-33 \%$ sava darba laika spiesti veltīt medmāsu un sanitāru darbam. Pietrūkst arī materiālu [46].

1990. gadā tika nodibināta Latvijas Stomatologu asociācija. Sakarā ar to, ka Latvijā strādāja stomatologi no bijušās Padomju Savienības ar dažādiem diplomiem un pẽcdiploma izglîtỉbu (vai bez tās), kā arī, lai aizsargātu pacientu intereses un noteiktu zobārstu profesionālās zināšanās, asociācija organizẹja sertifikāciju. Tai bija divas dalas: teorētiskā (170 jautājumu) un praktiskã (pacienta apskate, diagnozes noteikšana, ārstē̌̌anas plāns) [47]. Vēlāk to papildināja ar dentālās rentgenogrammas aprakstu, jautājumiem par pirmo palīdzỉbu un zobārstniecības instrumentu sterilizācijas noteikumiem. 1993. gada aprīlī bija sertificēts 91 stoma- 
tologs, tika pieñemti 140 iesniegumi [48], tā paša gada jūnijā sertificēts bija jau 171 stomatologs un pieņemti 155 iesniegumi [49], bet 1993. gada novembrī sertificêto stomatologu bija jau 255 [50].

90. gados KPE indekss (kariozie, plombētie un ekstrahētie zobi) divpadsmitgadīgiem bērniem ir 5,8. Visā pasaulē mutes dobuma veselības stratēgija un taktika bija vērsta uz to, lai 2000. gadā šis indekss nebūtu lielāks par 3.

Novērtējot audus ap zobiem, konstatēts, ka tikai 15\% divpadsmitgadīgo bērnu nav asiṇošanas no smaganām un zobakmens. Vēl arvien pietrūkst ārstnieciskā un profilaktiska darba palīgpersonāla [51]. Ir gadījumi, kad pie zobārsta nonāk gadu veci bērni ar karioziem zobiem. Stomatolog̉iskās slimības ir gandrīz visiem iedzīvotãjiem. Pēc šã rādītāja Latvija ieņem vienu no pirmajām vietām pasaulē.

1993. gadā zobu un žoklu anomālijas satopamas 54,6\% iedzīvotāju. Aktīva ārstēšana, izmantojot specializētu aparatūru, nepieciešama 20,3\% bērnu. Zīmīga ir 1993. gada statistika:

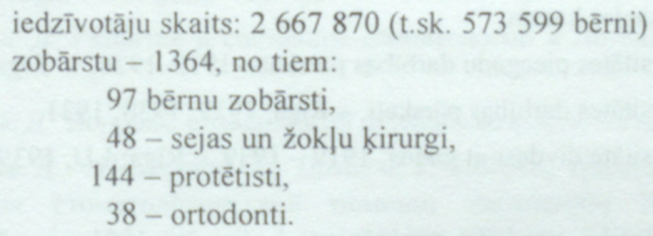

Stomatologiskā palīdzība tiek sniegta valsts iestādēs, municipālajās iestādēs, sabiedrībās ar ierobežotu atbildību (SIA), privātās prakses kabinetos [52].

\section{Literatūra}

1. Vīksna A. Dodot gaismu, sadegu. - Rīga: Zvaigzne, 1983.

2. Денисова P. Эпохальные изменения строения нижней челюсти на территории Латвии// Труды московского общества испытателей природы: Человек. Москва, 1972. - Т.43. - С. 149-161.

3. Блумберга $M$. Зубоврачебная помощь в Латвии в досоветский период/ 1 съезд социал-гигиенистов, организаторов здравоохранения и историков медицины Латв. ССР. - Рига, 1984. - С. 154-155.

4. Derums $V$. Baltijas sencilvēku slimības un tautas dziedniecība. - Rīga: Zinātne, 1988.

5. Derums $V$. Tautas veselība un dziedniecība senajā Baltijā. - Rīga: Zinātne, 1978.

6. Дерумс В. Некоторые данные истории медицины Прибалтики по археологическим материалам// Из истории медицины. - Рига, 1973. - Т. 9. - С. 77-83.

7. Padomju Latvijas Ārsts. - Rīga, 1940.- Nr.3. - 184.-186. Ipp.

8. Список средних и низших медицинских школ: Гражданские ведомства в России. - С. Петербург, 1910. - С. 2. 
9. Blumberga $M$. leskats Latvijas zobārstu biedrïbu vēsturē// Latvijas Ārsts. - Rīga, 1993. - Nr.1. - 80,-81. Ipp.

10. Latviešu Zobārstu biedrỉbas protokolu grāmata: 1909-1934// Latvijas Medicīnas akadēmijas Stomatologiijas fakultātes arhīvs.

11. Jannaus $K$. Slimi zobi kā citu slimību cēlonis. - Rīga: Erva, 1937.

12. Latviešu Zobārstu Biedrības Rakstu Krājums. - Rīga, 1932. - Nr.1.

13. Latviešu Zobārstu Biedrības Rakstu Krājums. - Rīga, 1932. - Nr.2.

14. Zobārstniecības Raksti. - Rīga, 1938. - Nr.1.

15. Latviešu Zobārstu Biedrības Rakstu Krājums. - Rīga, 1938. - Nr.8.

16. Stomatologijas Apskats. - Rīga, 1929. - Nr.2.

17. Stomatologijas Apskats. - Rīga, 1928. - Nr.1.

18. Stomatologijas Apskats. - Rīga, 1928. - Nr.2.

19. Grīnbergs $E$. Izraksti no Latvijas vēstures arhīva par zobārstu biedrību darbību laikā līdz II Pasaules karam.

20. Latvijas Universitātes piecgadu darbības pārskats: 1919-1924. - Rīga, 1925.

21. Latvijas Universitātes darbïbas pārskati. - Rīga, 1929; 1930; 1931.

22. Latvijas Universitāte divdesmit gados: 1919 - 1939. - Rĩga: LU, 1939. - I. dala. 671.-698. Ipp.

23. Latvijas medicīniskā pārskata saraksts uz 1. janvāri 1921.g. - Rīga: Valsts Veselības Departaments.

24. Блумберга М. К истории сюматологии в Латвии (1920-1930 гг.)// Актуальные вопросы музееведения: Тез. докл. - Рига, 1982. - С. 184-188.

25. Barons $K$. Zobārstnieciskā palīdzỉba bērniem līdz skolas beigšanai. - Rīga: Latvijas Sarkanais Krusts, 1939.

26. I. Latvijas Ārstu un Zobārstu kongresa darbi. - Rīga, 1926.

27. Stomatologijas Apskats. - Rīga, 1928. - Nr. 4. - 5.-6. Ipp.

28. II. Latvijas Ārstu un zobārstu kongresa darbi. - Rīga, 1926.

29. III. Latvijas Ārstu un zobārstu kongresa darbi. - Rīga, 1932.

30. Blumberga $M$. Bērnu zobārstniecỉba Latvijā// Medicīna. Vēsture. Valoda. - Rīga, 1993. - 13.-14. Ipp.

31. Stomatologijas attīstỉba Latvijas PSR. - Rīga: LPSR Veselības Aizsardzỉbas ministrija, 1967. - 120 lpp:

32. Профилактика и раннее лечение стоматологических заболеваний. - Рига, 1972.

33. Передовые формы организации работы лечебно-профилактических учреждений. - Рита, 1973.

34. Jingensone I. Mūsu republikas stomatologiskais dienests// Veselība. $-1971 .-\mathrm{Nr}$. 6. - 19.-20. Ipp. 
35. Bākulis I. Kirurg̉iskās stomatologijas attīstỉba mūsu republikā// Veselība. - 1970. - Nr. 4. - 7.-9. Ipp.

36. Būmeistere $V$. Ķirurg̀iskãs stomatologijas perspektīvas// Veselība. - 1969. - Nr. 4. $-15 .-16$.

37. Terapeitiskās stomatologijas sasniegumi. - Rīga, 1970.

38. Protētiskās stomatologijas sasniegumi. - Rīga, 1970.

39. Birkerts P. Latvju tautas estētika. - Rīga, 1938. - 1. sēj. - 142. - 151. Ipp.

40. Pakalns G. Ortodontijas attīstības Latvijā// Katram Latvijas Zobārstam! - Rīga, 1993. - Nr. 2. - 6.-7. Ipp.

41. Лебедькова $M$. Восстановление и развитие высшей медицинской школы в Латвии в первые послевоенные годы $(1944-1950) / /$ Из истории медицины. Рига, 1973. - Том 9. - С. 16. - 25.

42. Pakalns G. Stomatologiska izglītiba Latvijā// Pasaules Latviešu Ārstu 2. Kongresa tēzes. - Rĩga, 1993. gads. - 52. lpp.

43. Калвелис Д. Развитие и состояние стоматологии в Латвийской ССР. - Рига, 1967.

44. Калвелис Д. Вопросы стоматологии детского возраста. - Рига, 1968. - С. 9- 16.

45. Калвелис Д., Паэглитис А., Пакалнс Г. Истоки, традиции и перспективы развития стоматологической помощи населению Латвийской ССР// Стоматологическая помощь. - Рига: РМИ, 1988.

46. Grãvīte E. Stomatologija// Latvijas Ärsts. - Rīga, 1989. - Nr. 4. - 24.-26. Ipp.

47. Treimane L. Latvijas zobārstu asociācijas pirmie divi gadi// Latvijas Ārsts. - Rīga, 1993. - Nr. 1. - 85.lpp.

48. Katram Latvijas Zobārstam! - Rĩga, 1993. - Nr. 1. - 2. Ipp.

49. Katram Latvijas Zobārstam! - Rīga, 1993. - Nr. 3. - 2. Ipp.

50. Katram Latvijas Zobārstam! - Rīga, 1993. - Nr. 7. - 2. Ipp.

51. Senakola E., Brinkmane A. Veselīgi smaidi - priecīgai pasaulei!// Pulss. - 1994. Nr. 15. - 1. Ipp.

52. Paeglītis A., Jirgensone I. Latvijas zobārstniecība// Pasaules Latviešu Ārstu 2. Kongresa têzes. - Rīga, 1993.-71. Ipp.

\section{The Development Dentistry in Latvia (Summary)}

By Juris Erenpreiss and Andrejs Ivanovs

The work reflects the development of dentistry in Latvia from the middle of the $19^{\text {th }}$ century up to the beginning of the 21 .century. The first dentistry schools and the dentists association have been described in the twenties of the beginning of the $20^{\text {th }}$ century at the Medical faculty of Latvia's University as well as the importance of Latvia's doctors and dentists congresses in the development of dentistry. A short 
description is given of the role of children's sugary therapeutics, prosthetics and orthodontics in the development of Latvia's dentistry after World II.

\section{Juris Ërenpreiss}

Rīgas Stradiņa Universitātes Ģimenes medicīnas katedras docētājs

A. Saharova 16, Rīga, LV 1021

Tel. 7178697, e-mail: family.center@latnet.lv

\section{Andrejs Ivanovs}

Latvijas Universitātes Biomedicīnas pētījumu un studiju centra Vēža šūnas biologijas laboratorijas asistents

Rātsupītes 1, Rīga, LV 1067

Tel.7808220, e-mail: cancer@latnet.lv 